NBER WORKING PAPER SERIES

\title{
CROSS-BORDER LISTINGS, CAPITAL CONTROLS, AND EQUITY FLOWS TO EMERGING MARKETS
}

\author{
Hali J. Edison \\ Francis E. Warnock \\ Working Paper 12589 \\ http://www.nber.org/papers/w12589 \\ NATIONAL BUREAU OF ECONOMIC RESEARCH \\ 1050 Massachusetts Avenue \\ Cambridge, MA 02138 \\ October 2006
}

This work was initiated while both authors were in the Division of International Finance at the Board of Governors of the Federal Reserve System. We thank for helpful comments and suggestions Campbell Harvey, Jean Imbs, Andrew Karolyi, Assaf Razin, Leigh Riddick, Linda Tesar, Jonathan Wright, and participants at the following conferences and seminars: CEPR/London Business School Conference on International Capital Flows, Federal Reserve Board, Federal Reserve Bank of New York, Kellogg School of Management Conference on Investments in Imperfect Capital Markets, University of Sydney, Washington Area Finance Association, Western Economic Association, and World Bank. We also thank Jean Tobin at the NYSE for data on listings of foreign stocks; Alka Banerjee of Standard and Poor's for helping us with the S\&P/IFC data; and Nancy Baer, Jill Faucette, Sara Holland, and Ben Sutton for research assistance. The views in this paper are solely the responsibility of the authors and should not be interpreted as reflecting the views of the International Monetary Fund or of any other person associated with the IMF. Warnock thanks the Darden School Foundation for generous support. The views expressed herein are those of the author(s) and do not necessarily reflect the views of the National Bureau of Economic Research.

(C) 2006 by Hali J. Edison and Francis E. Warnock. All rights reserved. Short sections of text, not to exceed two paragraphs, may be quoted without explicit permission provided that full credit, including (C) notice, is given to the source. 
Cross-border Listings, Capital Controls, and Equity Flows To Emerging Markets

Hali J. Edison and Francis E. Warnock

NBER Working Paper No. 12589

October 2006

JEL No. F21,F3,G15

\begin{abstract}
We investigate the impact of two types of financial liberalizations on short- and long-horizon capital flows to emerging markets in a framework that controls for push and pull factors. The first type of liberalization, a reduction in capital controls, is countrywide but uncertain, because its extent and permanence is not known with certainty. The second type, a cross-border listing, is a firm-level liberalization that has no uncertainty. Consistent with theoretical predictions, we find that the deterministic cross-listing results in an immediate but short-lived increase in capital inflows. In contrast, the uncertain reduction in capital controls results in increased inflows only over a longer horizon, if at all.
\end{abstract}

\author{
Hali J. Edison \\ International Monetary Fund \\ Asia and Pacific Department \\ Washington, DC 20431 \\ hedison@imf.org \\ Francis E. Warnock \\ Darden Business School \\ University of Virginia \\ Charlottesville, VA 22906-6550 \\ and NBER \\ warnockf@darden.virginia.edu
}




\section{Introduction}

Most of the nearly 200 countries in the world have some form of barriers to inward international investment, and some of these barriers are severe. Event study findings of Bekaert et al. (2002) and Edison and Warnock (2003) indicate that capital inflows increase after an initial liberalization, but liberalizations are almost never complete, one-time events (Bacchetta and van Wincoop, 2000; Bekaert and Harvey, 1995). In this paper we ask the question, What is the effect of a marginal liberalization on short- and long-horizon capital inflows? To answer this we focus on equity flows from the United States to nine major emerging markets while controlling for various 'push' and 'pull' factors previously determined to affect capital flows.

We examine two types of financial liberalizations. The first is a change in a country's international investment restrictions. To quantify this type of liberalization, we use the first difference of the Edison and Warnock (2003) monthly measure of the intensity of capital controls. The measure captures not only the date of the initial opening of a market, but also the extent of that opening and the evolution and intensity of subsequent changes in controls. Such liberalizations are countrywide but entail some uncertainty, in particular because the permanence of the liberalization may not be known.

The second type of liberalization that we study, the cross-border listing of an individual emerging market equity on a global equity market, is less broad but more certain. We think of a cross-listing as a firm-level liberalization that owes, perhaps, to an improvement in the quality of financial information. Emerging equity markets not only have higher transaction costs and a greater likelihood of failed trades, but also potentially poor financial information that reflects varied accounting practices, disclosure requirements, and enforcement. All of these costsdirect and informational—are alleviated when a foreign firm lists on a U.S. exchange. For 
example, the cross-listed firm opts into the information environment inherent in U.S. investor protection regulations, which include reconciliation to U.S. GAAP and adherence to the SEC's disclosure requirements and securities laws. Existing empirical evidence is consistent with this view of a cross-listing as a firm-level liberalization. Compared to firms that are only available on home exchanges, cross-listed firms have higher valuations (Doidge, Karolyi, and Stulz, 2004), more accurate analyst forecasts (Lang et al. 2003a), less evidence of insider trading (Tribukait, 2003), more informative financial reporting (Lang et al. 2003a; Lang et al. 2003b; Leuz et al. 2003; Barth et al. 2006), and greater U.S. participation (Edison and Warnock, 2004). Moreover, we think of a cross-listing as a deterministic liberalization, the extent and permanence of which is known with certainty; the costs the firm incurs to initially cross-list are likely sufficiently large to inhibit a reversal in the liberalization (a delisting). In our sample, there were no voluntary delistings. ${ }^{1}$

The theoretical work of Bacchetta and van Wincoop (2000) provides guidance as to the likely effect of country-wide liberalizations of uncertain permanence (i.e., reductions in capital controls) and permanent firm-specific liberalizations (cross-listings). In their model-a simplified version of which is presented in Section 2-permanent liberalizations that are known with certainty result in a sharp, temporary increase in inflows as investors immediately rebalance their portfolios to incorporate the newly available securities. Long-run inflows increase too, but not to the extent of the temporary increase. In contrast, if the liberalization is uncertain, the

\footnotetext{
${ }^{1}$ Delistings in our sample occurred because the company fell below minimum NYSE requirements for trading and size (5); went bankrupt (1); or merged or restructured (2). The reader might believe, due to the furor over Sarbanes Oxley, that many foreign firms want to delist. However, there is no evidence that this is true for the exchange-listed firms that we focus on. These firms have a very substantial portion of their shareholder bases in the United States, with median U.S. holdings of cross-listed firms at $24 \%$ of market capitalization (Edison and Warnock, 2004). For a careful study of deregistrations (which are distinct from delistings), see Leuz et al. (2006).
} 
initial increase is attenuated; long-run flows still increase, more so as the uncertainty is resolved, but the sharp initial inflow is absent.

We gauge the impact of the two types of liberalizations in an empirical framework that controls for global push factors and country-specific pull factors. In line with previous research we find important roles for push factors such as U.S. economic activity and U.S. interest rates. ${ }^{2}$ We also find limited evidence that investors chased past returns. ${ }^{3}$ Controlling for these factors, our results on financial liberalizations are largely in line with the predictions of the Bacchetta and van Wincoop (2000) model. Deterministic firm-level liberalizations (cross-listings) result in an immediate surge in capital inflows, but with little if any follow through. Country-level liberalizations, which are more uncertain, do not lead to immediate inflows, but rather to increased inflows over a longer horizon; in our sample, this is particularly evident in Asia.

The paper is organized as follows. The next section presents the underlying theoretical model. Section 3 describes the data used in our empirical analysis: capital flows data, our capital controls and cross-border listings variables, and standard push and pull factors. Section 4 presents our panel regression results. Section 5 contains concluding remarks.

\section{Barriers to International Investment and Capital Flows}

\footnotetext{
${ }^{2}$ Chuhan et al. (1998) found that push factors-the decrease in U.S. interest rates and the slowdown in U.S. industrial production-help explain flows to both Latin American and emerging Asian countries from 1988 to 1992, and that pull factors such as equity returns or credit ratings matter for flows to Asia but not necessarily for Latin American flows. Calvo et al. (1993) also find evidence of an important role for global push factors. See Griffin et al. (2004) for recent evidence on push (and pull) factors.

${ }^{3}$ The evidence on returns-chasing behavior is mixed. Using monthly data, Bohn and Tesar (1996) find that investors chase past returns in some markets. The literature that focuses on information asymmetries using high frequency flows provides conflicting evidence; see, for example, Dvorak (2005), Choe et al. (2005), and Seasholes (2000). Utilizing the more advanced techniques of Grinblatt et al. (1995), Thomas et al. (2006) find no evidence of returns chasing.
} 
The theoretical model underlying our empirical work is one of international barriers to investment. Black (1974) and Stulz (1981) model barriers as taxes that reduce returns. Bacchetta and van Wincoop (2000) also model barriers in this manner but in a dynamic setting that enables them to trace out the impact on capital flows of deterministic and uncertain liberalizations. In this subsection, we present a simplified version of the Bacchetta and van Wincoop (2000) model. ${ }^{4}$

Specifically, assume that U.S. investors choose how to allocate their wealth, $W$, between U.S. equities and the equities of $J$ emerging markets. Period $t$ returns on U.S. equities are given by $r_{U S, t} \sim N\left(\mu_{U S}, \sigma_{U S}^{2}\right)$. Let $\mu_{j t} \sim N\left(\bar{\mu}_{E M}, \sigma_{E M}^{2}\right)$ be returns on equities in emerging market $j$. For U.S. investors, these emerging market returns are subject to a foreign investor tax, $\tau_{\mathrm{jt}}$, so that net returns in emerging market $j$ are

$$
r_{j t}=\mu_{j t}-\tau_{j t},
$$

with expected return $\bar{r}_{j t}=\bar{\mu}_{E M}-\tau_{j t}$. For simplicity, assume that returns are uncorrelated across countries and $\sigma_{U S}^{2}=\sigma_{E M}^{2}$. Investors have exponential utility function $U(C)=e^{-\theta C}$, with consumption equal to the portfolio return, $R_{t}$, times $W$. Thus, U.S. investors choose portfolio allocations to maximize period $t$ utility that is a function of the mean-variance tradeoff:

\footnotetext{
${ }^{4}$ There are other models of capital flows. For example, in the models of Brennan and Cao (1997), Brennan et al. (2005), and Griffin et al. (2004), information asymmetries between foreign and domestic investor influence the relationship between flows and returns.
} 
$\max _{\alpha_{j t}} E\left(R_{t}\right)-\frac{\gamma}{2} \operatorname{var}\left(R_{t}\right)$

where $\mathrm{j} \in[1, \mathrm{~J}+1]$, the US is the $(J+1)^{\mathrm{st}}$ equity market, $\alpha_{\mathrm{jt}}$ is the weight of market $j$ in the portfolios $\left(\sum_{j=1}^{J+1} \alpha_{j t}=1\right), \gamma=\theta W$, and $R_{t}$ is portfolio returns given by

$R_{t}=\sum_{j=1}^{J} \alpha_{j t} r_{j t}+\alpha_{J+1, t} r_{U S, t}$

Defining average expected returns in emerging markets as $\bar{r}_{t}=\sum_{j=1}^{J} \bar{r}_{j t} / J$, the portfolio weight in emerging market $j$ is given by:

$\alpha_{j t}=\frac{1}{1+J}+\frac{\bar{r}_{j t}-\frac{J \bar{r}_{t}+\mu_{U S}}{J+1}}{\gamma \sigma^{2}}$.

The first term of (4) proscribes equal weights on each country in the world $(J$ emerging markets and the US). Risk is assumed to be constant across countries, so deviations from equal weights arise through differential expected returns. In particular, the second term puts greater weights on emerging markets with expected returns that exceed the world average. If country $j$ liberalizes (modeled as a reduction in $\tau_{\mathrm{j}}$ ), inflows occur: 


$$
\frac{\partial \alpha_{j}}{\partial \tau_{j}}=\frac{-J}{(J+1) \gamma \sigma^{2}}
$$

Bacchetta and van Wincoop (2000) solve the dynamics of capital flows for a more general version in which the liberalization-induced inflows are subject to installation costs, which produces nonlinearities in the dynamics of inflows. In addition, they allow for learning by market participants; liberalizations may be deterministic and known by all or uncertain. As (5) indicates, deterministic liberalizations result in a surge in inflows that then tapers off. In contrast, liberalizations that require learning by market participants lead to increased inflows that are smaller initially (compared to a deterministic liberalization) but increase as the uncertainty is resolved.

For our purposes, the dismantling of capital controls at the country level and the firmlevel international cross-listing of an equity are both international financial liberalizations, albeit of different natures. Country-level capital controls can be reduced, but such changes are not certain, even after they have been announced. For example, countries have been known to reimpose capital controls_-recent examples are Argentina in 2001 and Malaysia in 1998—so the true extent of any liberalization can only be learned over time and even then not with certainty. ${ }^{5}$ An individual firm's cross-listing, especially on an exchange that requires more stringent financial disclosure than the home exchange, can also be considered a liberalization. In this case the liberalization is not countrywide, but also does not come with the uncertainty of changes in capital controls. All of the necessary information for the cross-listing must be in order before the

\footnotetext{
${ }^{5}$ There are times when capital controls shut down trading in ADRs; see, for example, the Argentine case in Auguste et al. (2006). In our opinion, these are best thought of as changes in capital controls, not an undoing of an ADR program.
} 
event, so in effect the "liberalization" is known with certainty at the time of the listing. ${ }^{6}$ Based on the model, we would expect inflows to increase over time with a countrywide liberalization but immediately with a cross-listing. Before turning to an empirical test of the model, in the next section we present the various data in more detail.

\section{The Data}

In this section we discuss details of the data on bilateral capital flows, financial liberalization at both the country- and firm-level, and push and pull factors.

\subsection{Bilateral Equity Flows: A Short Primer}

The capital flows data we analyze are monthly portfolio equity flows from the United States to emerging market countries, compiled by the U.S. Treasury International Capital (TIC) Reporting System. U.S. net purchases of securities in a given country are defined as gross purchases of foreign securities by U.S. residents from residents of that country minus gross sales of foreign securities from U.S. residents to residents of that country. ${ }^{7}$

\footnotetext{
${ }^{6}$ One sometimes hears that trading in ADRs dries up. This must refer to Level I (OTC) ADRs, which are not included in our cross-listing variable; we know of no evidence that exchange-listed ADRs have dried up. From the Edison and Warnock (2004) data set on holdings, only 3 of 55 exchange-listed ADRs from the nine countries in our sample have U.S. holdings of less than $7 \%$ of market capitalization. Given home bias, even $7 \%$ is a large amount. Median U.S. holdings for these exchange listed ADRs is a sizeable 24\% of market capitalization. Level 1 OTC ADRs do dry up; almost half the 71 Level I ADRs in the Edison and Warnock (2004) holdings data set have U.S. holdings of less than 7\%, with some near zero. We do not consider Level I ADRs "cross-listed".

${ }^{7}$ Griever et al. (2001) is a primer on the TIC data, which have been used in Tesar and Werner (1994), Brennan and Cao (1997), Taylor and Sarno (1997), Chuhan et al. (1998), and Bekaert et al. (2002). The TIC flows are also the basis of the U.S. portion of the Portes and Rey (2005) data set. Other sources on
} 
To set the scene, Table 1 presents portfolio equity flows to Latin America and Asia in the broader group of all private capital flows from all (including non-U.S.) investors. Portfolio equity flows are usually smaller than direct investment or bond flows, and their share can be quite volatile. In both Latin America and emerging Asia, the share of equity inflows increased in the early 1990s and peaked in 1993. By 1998, global equity flows had all but dried up in Latin America, but were somewhat more resilient in Asia; in 1999 equities represented 34 percent of net inflows into Asia.

We focus on the 1990s, a period during which many countries liberalized their financial markets and many emerging-market firms cross-listed. Figure 1, which depicts U.S. flows to Latin America and Emerging Asia as a percentage of regional market capitalization, gives a sense of the nature of U.S. monthly capital flow data during this period and illustrates three facts. First, U.S. investors moved into Latin American equity markets in the early 1990s, but did not begin to invest large amounts in Asian emerging markets until a few years later. Second, the effects of two crises are evident. The Mexican crisis of 1994 coincided with a prolonged period of relatively small inflows to Latin America, but only a brief pause in flows to Asia. In contrast, the effects of the Asian financial crisis of 1997/1998 appear to be greater in Latin American countries, in which U.S. investors sold equities on net, than in Asia, where equity purchases by U.S. investors only slowed. Finally, the figures highlight a feature of the flow data that any

capital flows data exist. The sudden stops literature typically uses annual or quarterly global (not bilateral) flows from the IMF'S International Financial Statistics database (e.g., Frankel and Cavallo, 2004). High frequency capital flows data are available from proprietary sources, although it is difficult to gauge the scope of their coverage. Froot et al. (2001) use proprietary data that include only transactions by State Street clients for which the countries of the currency and the foreign equity are the same. This excludes trading in ADRs, which are likely a large and variable portion of cross-border trading (Pulatkonak and Sofianos, 1999; Ahearne et al. 2004). Our data include transactions in ADRs. High frequency flows over short periods have also been analyzed by Richards (2005) and Griffin et al. (2004). 
modeling approach must address, the lumpiness in equity purchases that appears as large spikes in the data.

There are three aspects of the monthly TIC data that can confound the analysis of capital flows: coverage is limited to flows that involve U.S. residents, trades through third countries result in a geographical bias in bilateral flows data, and equity financing of cross-border mergers makes it increasingly difficult to analyze equity flows. In the remainder of this subsection, we briefly consider the effects of these three issues on our sample.

Coverage Limited to U.S. Investors. The TIC data are bilateral portfolio flows into and out of the United States and, hence, do not include other countries' investments in emerging markets. The ideal data for a study of capital flows is a world matrix of flows at the highest frequency possible, with the $i, j$ element giving the net flow from country $i$ into country $j$ 's securities. Such a data set does not exist, as very few countries collect bilateral capital flows data. As Table 2 implies, equity flows from other countries are also important, with the share of U.S. to global flows to these regions ranging from 15 to 50 percent. However, because so few countries collect bilateral capital flows data, the coverage of the TIC data is quite good.

Trades through Third Countries. A strong but common assumption-that the countries of the foreign intermediary and foreign issuer are identical—must be made when using transactions-based capital flows data. It is by now well understood that capital flows data collected for balance of payments purposes are based on the country of the foreign intermediary, which is not necessarily the country in which the issuer of the foreign security resides. The assumption that the countries of the intermediary and issuer are the same is clearly is not true for trades through financial centers, which skew the geography of capital flows. Warnock and Cleaver (2003) showed that this geographical bias is severe for financial centers such as the 
United Kingdom, but not for emerging market regions. To determine whether the TIC data for the countries in our sample are accurate, we followed Warnock and Cleaver (2003) and used the flows data to estimate positions which we then compared to the positions reported in the 1997 Benchmark Survey of U.S. Holdings of Foreign Securities. ${ }^{8}$ While there are many variables that go into the calculation of the estimates—for example, valuation adjustments—egregious discrepancies between the estimate and the survey amount would suggest problems with the country attribution of the capital flows data. Results of this comparison (not shown) indicate that, with the possible exception of Brazil, the TIC flows data appear to be rather accurate for these countries.

Merger-Related Stock Swaps. Cross-border mergers and acquisitions have been increasingly financed by "stock swaps" whereby shareholders of the target company receive shares in the new (or existing) foreign company. For example, when Daimler acquired Chrysler, shares of Chrysler were "swapped" for Daimler Chrysler shares. Such acquisitions are not included in the TIC data, but any "flowback" is. ${ }^{9}$ This has a greater impact on studies of industrial country capital flows, such as flows opposite Germany or the United Kingdom, because of the large Daimler Chrysler and BP Amoco mergers. The bottom line of Table 2 shows, however, that stock swaps do not affect our emerging markets sample.

\footnotetext{
${ }^{8}$ The survey is available at www.treas.gov/fpis.html.

${ }^{9}$ Consider three strategies that were available to Chrysler shareholders who were content with the share of foreign equities in their portfolios prior to the swap. They could have sold Chrysler after the merger was announced but before it occurred, which would have no confounding effect on capital flows data. If they decided that Daimler Chrysler was a better way to get exposure to Germany than other German equities, they might have rebalanced their portfolios by selling other German stocks before or after the swap. Such sales would appear in the TIC data, so the offsetting swap should be added to the flows data as a purchase. Finally, they could have sold Daimler Chrysler after the swap, which would also appear as sales in the TIC data; again, the offsetting swap should be entered as a purchase. See Karolyi (2003) for a study of the Daimler Chrysler merger.
} 


\subsection{Financial Liberalization}

In this subsection we discuss the two variables that we use to capture international financial liberalization, a capital controls variable and a measure of cross-listings. ${ }^{10}$

\subsubsection{Capital Controls}

Many countries opened their financial markets to foreign investment to various degrees during our sample period. The post-liberalization increase in inflows has been documented in Bekaert et al. (2002) and Edison and Warnock (2003). However, the liberalization process is not a one-time event that is uniform across countries, as financial liberalizations vary greatly in their extent (full or incomplete) and evolution (one-time event or gradual). To capture the potentially gradual nature of liberalizations, we use the first difference of the monthly measure of the intensity of capital controls developed in Edison and Warnock (2003). ${ }^{11}$ The measure uses the fact that the International Finance Corporation's Global Index (IFCG) is designed to capture the entire market and an individual stock's weight in the Investable Index (IFCI) is determined mainly by legal restrictions. Thus, the ratio of the market capitalizations behind the IFCI and IFCG is an indication of a country's openness, and the following formula provides a measure of the intensity of foreign ownership restrictions, FOR:

\footnotetext{
${ }^{10}$ On the link between domestic and international financial liberalization, see Levine (2001).

${ }^{11}$ Other measures of capital controls exist, but most are either annual or do not capture the intensity of controls. See, for example, Alesina et al. (1994), Quinn (1997), Rodrik (1998), Montiel and Reinhart (1999), and the survey by Eichengreen (2001).
} 
$F O R_{i, t}=1-\frac{M C_{i, t}^{I F C I} / P_{i, t}^{I F C I}}{M C_{i, t}^{I F C G} / P_{i, t}^{I F C G}}$

Where, for country $i, P$ denotes the IFC price indices and $M C$ denotes the market capitalization of the particular index. Deflating by the price indices eliminates relative market capitalization changes that might arise from asymmetric shocks to investable and global stocks. ${ }^{12}$ The measure-which can vary from zero (completely open) to one (completely closed to foreign invesment) — is narrow in that it focuses on just one component of capital controls, but is appropriate for modeling equity flows.

Figure 2, which shows regional (market capitalization weighted) aggregates of the country-level measure of foreign ownership restrictions from 1989 through 2000, underscores regional differences in initial liberalizations and the evolution of the liberalization process. Latin American economies liberalized much earlier and more completely than emerging Asia, where the liberalization process was more gradual and, in Malaysia, partially reversed in the late 1990s. In our empirical work, we use the first difference of $F O R_{i, t}$ for each country $i$.

\subsubsection{Cross-Border Listings}

The wave of cross-border listings of emerging market equities began in earnest in the 1990s. On U.S. exchanges, the equity can be directly listed, but the usual vehicle is a listing

\footnotetext{
${ }^{12}$ If, for example, bank stocks are not available to foreigners, a pure banking sector shock would change the relative price of investable stocks and, hence, change relative market capitalizations.
} 
through a Level II or Level III ADR. The potential advantages of listing on a U.S. exchange include an enlarged investor base, increased visibility, a highly liquid secondary market, and the opportunity to raise new capital. ${ }^{13}$ As noted in the introduction, from the investor's perspective the cross-listing mitigates some of the uncertainties and costs involved with making direct purchases in foreign markets.

Our cross-border listing variable, $C B L_{i, t}$, includes equities that are listed on U.S. exchanges either directly or as exchange-traded (or Levels II and III) ADRs, because these are the only foreign securities that are subject to the SEC's stringent disclosure and reconciliation requirements. ${ }^{14} C B L_{i, t}$ is the share country $i$ 's stock market that is newly listed on a U.S. exchange in month $t$. For example, BAESA's market capitalization was $2.3 \%$ of total Argentinian market capitalization when it listed on the NYSE in May 1993; in that month, $C B L$ is 0.023 for Argentina. Figure 3 depicts, for the month of a cross-listing, the market capitalization of the newly cross-listed firm as a percentage of regional market capitalization. The figure illustrates that Latin American cross-listings came in waves; they began in the early 1990s, surged in 1993 and 1994, slowed with the Peso crisis of December 1994, and picked up by 1997 only to slow again with the Asian financial crisis. In contrast, Asian cross-listings were much more muted and less frequent. Finally, the effect of the Asian financial crisis is clear in

\footnotetext{
${ }^{13}$ Studies of cross-listing behavior include Karolyi (1998), Pagano et al. (2002), Lins et al. (2005), and Claessens et al. (2002).

${ }^{14}$ In U.S. capital flows data, ADRs are treated just as any other foreign stock. Transactions between a U.S. resident and a foreign resident are recorded, while those between two foreign or two domestic parties are not. The depository bank, it should be noted, has only fiduciary responsibilities and does not take part in transactions; therefore, it does not create capital flows. We do not consider other types of crosslistings, such as private placements (through rule 144A) or over-the-counter (Level I and unsponsored) ADRs. These do not benefit from U.S. investor protection regulations, but may have reduced transaction costs compared to securities that trade only in emerging markets, because the need to hire a global custodian in the local market is circumvented and liquidity may be better in New York; see Karolyi (2004) for evidence on these securities.
} 
Figure 3b; no firm from emerging Asia listed on a U.S. exchange between the fall of 1997 and mid-1999.

\subsection{Proxies for Expected Risk and Return}

In our empirical work we control for factors that have been identified in the capital flows literature. Net equity inflows into emerging markets should be related to changes in expected risk and return. No direct measures of expected risk and return are available, so we follow the literature and rely on proxies—-the so-called global "push" and country-specific "pull" factors.

We include two country-specific factors that capture past and prospective returns. As in Bekaert et al. (2002), we include lagged excess returns (excess of the foreign market over the U.S. market) to capture returns-chasing or positive feedback trading. For expected returns, we use the dividend-price ratio, or dividend yield, which has been shown to have forecasting power for returns (Fama and French, 1988; Campbell and Shiller, 1988; Harvey, 1995). If U.S. investors chase past (prospective) returns, an increase in past returns (dividend yields) should be associated with increased capital inflows.

For a risk measure we use the log of the International Country Risk Guide's (ICRG) Composite Index, which Erb et al. (1996) show to have predicted power for expected returns. ${ }^{15}$ The ICRG rating is such that a higher number indicates less risk; controlling for expected returns, we expect higher ICRG risk ratings (that is, lower risk) to be associated with higher equity inflows.

\footnotetext{
${ }^{15}$ Credit spreads on secondary market debt prices are another indicator of investment prospects, but are not available for a wide range of countries and, where available, start only in the early 1990s.
} 
The global factors that we consider are U.S. interest rates and the deviation from trend growth in U.S. industrial production. As U.S. interest rates increase, so does U.S. investors' risk-free rate of return; for constant relative returns, foreign investment becomes less attractive and lower cross-border net purchases are likely. An increase in U.S. interest rates also increases borrowing costs for emerging markets, thereby reducing the expected profits of emerging market firms. Stronger economic activity in the United States points toward higher future profits for U.S. firms and, hence, less equity investment abroad; counteracting this, however, may be a wealth effect that prompts U.S. investors to invest more abroad. In our empirical work we utilize deviation from trend real-time industrial production as a measure of the strength of U.S. economic activity.

\section{Empirical Results}

We estimate regional (fixed effects) panel regressions in which the dependent variable is (average) monthly equity inflows from month $t$ to month $t+k$ scaled by local market capitalization, where $K=0$ (short-horizon one-month flows to gauge the immediate impact of financial liberalizations) or $K=11$ (long-horizon 12-month flows). ${ }^{16}$ In our regressions, variables proxying for expected risk and return—the push and pull factors—are dated at time $t-1$. The liberalization variables, $C B L$ and $F O R$, are dated at time $t$. Summary statistics for all variables

\footnotetext{
${ }^{16}$ Long-horizon regressions are often used when modeling stocks returns; see the discussion in Campbell et al. (1997). Note that the long-horizon regressions impose an overlapping structure on the data that induces correlation in the errors. To correct for this autocorrelation-which for 12-month ahead regressions cannot be of order greater than eleven - we use Newey and West (1987) standard errors that effectively widen traditional standard errors on persistent explanatory variables; see Valkonov (2003) for a recent critique.
} 
are presented in Table 3. Complete details on each variable are provided in the appendix. Specifically, we estimate the following equations for net U.S. purchases of stocks in country $j$ scaled by country $j$ 's market capitalization:

$$
\begin{aligned}
& \frac{\sum_{k=0}^{K} Y_{j, t+k}}{k+1}=\alpha+\beta_{0} \operatorname{RISK}_{j, t-1}+\beta_{1} R_{E T_{j, t-1}}+\beta_{2} D Y_{j, t-1}+\beta_{3} C B L_{j, t}+\beta_{4}\left(F O R_{j, t}-F O R_{j, t-1}\right) \\
& +\beta_{5} \operatorname{USIP}_{t-1}+\beta_{6} \operatorname{USBOND}_{t-1}+\eta_{t+k} .
\end{aligned}
$$

The independent variable is $Y_{j, t}$ for short-horizon regressions $(K=0)$ and $\sum_{k=0}^{11} Y_{j, t+k} / 12$ for longhorizon regressions $(K=11)$. The liberalization variables are:

$F O R_{t}-F O R_{t-1} \quad$ change in foreign ownership restrictions from period $t-1$ to period $t$ $C B L_{t} \quad$ new exchange-traded cross-border listing in period $t$.

Control variables include

RISK $_{t-1} \quad$ change in the ICRG Composite Risk Index from period $t$ - 2 to period $t-1$

$R E T_{t-1} \quad$ period $t-1$ returns relative to returns on S\&P500

$D Y_{t-1} \quad$ period $t-1$ dividend yield

$U_{S I P}$ period $t-1$ deviation of real-time U.S. industrial production from a linear trend USBOND $D_{t-1}$ period $t-1$ interest rate on a 10 -year U.S. Treasury bond. 
Table 4 presents our panel results on the determinants of short-horizon equity flows. The short-horizon results for our two liberalization variables are consistent with predictions of the Bacchetta and van Wincoop (2000) model. Firm-level liberalizations (CBL), which we argue are narrow but deterministic, resulted in a highly significant increase in inflows in both regions. The coefficients on CBL indicate that a new ADR program by a firm that is ten percent of the home market raises equity inflows that month by 0.746 percent of market capitalization in Latin America and 0.147 percent in Asia. In contrast, reductions in capital controls, which are countrywide but uncertain, do not result in short-horizon inflows. Indeed, the coefficient on FOR is positive for Latin America, suggesting that given the other control factors the infrequent reductions in Latin American capital controls in this period were associated with outflows. ${ }^{17}$

Turning to the control variables, in both Latin America and emerging Asia, U.S. factors are very important, in line with previous findings (Chuhan et al. 1998; Montiel and Reinhart, 1999; Calvo et al. 1993). Both higher U.S. interest rates (which can lead to higher borrowing costs and reduced output in emerging markets) and above trend U.S. economic activity (which could signal greater prospective profits and, hence, higher expected returns for U.S. companies) result in significantly lower equity flows to emerging markets. Consistent with Bohn and Tesar (1995) and Bekaert et al. (2002), there is partial evidence of returns chasing, as higher past returns result in greater inflows to Latin America. ${ }^{18}$ The level of risk, as measured by the ICRG Composite Index, is not significant for either region.

\footnotetext{
${ }^{17}$ The positive coefficient is driven by one country, Chile. There is considerable uncertainty as to when Chile reduced capital controls. IFC data would put the date at January 1996, whereas Edison and Warnock (2003) moved the liberalization to January 1992, the date of the change is legislation. If we date the large change in Chile's FOR at January 1996, the coefficient on FOR would be negative.

${ }^{18}$ However, see Thomas et al. (2006) for a more comprehensive study of returns-chasing behavior.
} 
Long-horizon regression results are presented in Table 5. The impact of the liberalization variables varies across the regions. A reduction in capital controls results in a significant increase in long-horizon equity flows to emerging Asia, but not to Latin America (where markets were mostly open throughout our sample). Counter, at least at first glance, to the predictions from the theoretical model that deterministic liberalizations should result in immediate inflows that taper off, cross-listings in Latin America result in a significant increase in long-horizon inflows. However, the coefficients for the cross-listing variable are much smaller than in the short-horizon regressions, suggesting that the portfolio rebalancing effect is important but shortlived. For example, a new Latin American ADR program by a firm that is ten percent of its home market and raises equity inflows in the month of the cross-listing by 0.746 percent of market capitalization (from Table 4), but only by 0.096 percent per month in the longer horizon (or 1.15 percent over the twelve-month period). For Asia, CBL is insignificant in the longhorizon regressions. Thus, much of the cross-listing effect for Latin America, and all of it for emerging Asia, occurs in the month of the listing. ${ }^{19}$ As in the short-horizon results, U.S. factors—especially U.S. economic growth—are important as well, but there is no evidence that pull factors affect long-horizon inflows.

Overall, the results in Tables 4 and 5 appear to provide evidence consistent with the Bacchetta and van Wincoop (2000) model. The results suggest that countrywide liberalizations do not result in immediate inflows but—at least in emerging Asia—do spark longer-horizon

\footnotetext{
${ }^{19}$ The cross-listing effect might be greater if the variable was based on the firm's float instead of its market capitalization, but float data are not available back to 1989. Also, abnormal returns prior to a cross-listing (Foerster and Karolyi, 1999; Miller, 1999) suggest that some buying occurs before the crosslisting.
} 
inflows. ${ }^{20}$ Deterministic firm-level liberalizations result in immediate inflows in both regions. In addition, U.S. factors play an important role.

\section{Conclusion}

Theory predicts that deterministic liberalizations should result in a sharp increase in inflows that then taper off, while inflows increase more gradually following uncertain liberalizations that require learning about their extent and permanence. We think of a crosslisting as a deterministic firm-level liberalization, and the more conventional countrywide financial liberalizations as being less certain. In line with the theory, we find that the crosslisting of an emerging market equity on a U.S. exchange results in sharp short-horizon inflows, whereas the reduction of capital controls results in inflows over longer horizons, at least in emerging Asia.

With country-level flows data, we can only speculate that the flows associated with a cross-listing are purchases of the cross-listed firm. Another alternative is that investors become more aware of the emerging market at the time of the cross-listing and reconsider all of its equities. However, evidence from Edison and Warnock (2004), which uses firm-level data on holdings (not flows), suggests that the listing effect might be limited to the cross-listed firm and not extend to other firms in the country. Combined with the results for country-level capital flows in this paper, this suggests that the firm gets funding at the time of the cross-listing and the story ends: The emerging market does not enjoy widespread foreign buying, nor does foreign

\footnotetext{
${ }^{20} \mathrm{We}$ also ran vector autoregressions (not shown). Evidence from the VARs are broadly consistent with our panel results. Given that it is unclear how to order the Cholesky decomposition, a careful VAR analysis would require 5040 ( 7 factorial) sets of 7 graphs, so we do not present these graphs.
} 
investment in the cross-listed firm subsequently increase. Future research, perhaps using daily security-level cross-border flow data, might be able to provide further evidence on this issue.

\section{Appendix: Description of Data and Sources}

The equity flows data we analyze are monthly portfolio equity flows from the United States to emerging market countries, compiled by the U.S. Treasury International Capital (TIC) Reporting System. U.S. net purchases of securities in a given country are defined as gross purchases of foreign securities by U.S. residents from residents of that country (column 12 in the standard TIC presentation) minus gross sales of foreign securities from U.S. residents to residents of that country (column 6). The data are available at www.treas.gov/tic/. Our CBL variable, formed using data on the worldwide market capitalization of foreign firms listed on U.S. exchanges, is taken mainly from the S\&P's Emerging Markets Data Base. We use firmlevel market capitalization data as of the month the firm cross-listed, except when the firm does not appear in the EMDB as of the listing month. In those instances, the market capitalization used is that of the first month EMDB data became available for that firm. In the event that the firm was never added to the EMDB, we turned next to Datastream and then, for a small number of firms, to the NYSE. Country-level market capitalization data are from the EMDB and coincide with the month of the firm-level data. Because international securities transactions are reported to the TIC system using settlement date accounting, we move to the following month any listing that occurs in the last two business days of a month. Our measure of the change in foreign ownership restrictions uses monthly price and market capitalization data from the IFC/S\&P Investable and Global Indexes. See Edison and Warnock (2003) for a complete 
discussion. Equity returns are from Morgan Stanley MSCI indexes (www.mscidata.com).

Dividend yields, from the IFC, are a trailing 12-month moving average of dividends divided by the current price level. The risk measure is the International Country Risk Guide's (ICRG) Composite Index; see Erb et al. (1996). Real-time U.S. industrial production data are available at www.phil.frb.org/econ/forecast/reaindex.html; see Croushore and Stark (2001) for a complete description. The U.S. interest rate on a medium-term U.S. bond is from the IMF's IFS data set. Countries included in panel regressions are Argentina, Brazil, Chile, and Mexico (for Latin America) and Indonesia, Korea, Malaysia, Philippines, and Thailand (for Emerging Asia). 


\section{References}

Ahearne, A., Griever, W., Warnock, F., 2004. Information costs and home bias: an analysis of U.S. holdings of foreign equities. Journal of International Economics 62 (2), 313-336.

Alesina, A., Grilli, V., Milesi-Ferretti, G.M., 1994. The political economy of capital controls. In Leiderman, L., Razin, A. (Eds.), Capital Mobility: The Impact on Consumption, Investment and Growth. Cambridge University Press, Cambridge.

Auguste, S., Dominguez, K., Kamil, H., Tesar, L., 2006. Cross-border trading as a mechanism for implicit capital flight: ADRs and the Argentine crisis. Journal of Monetary Economics, forthcoming.

Bacchetta, P., van Wincoop, E., 2000. Capital flows to emerging markets: liberalization, overshooting, and volatility. In Edwards, S., Capital Flows and the Emerging Economies. NBER and University of Chicago Press, Chicago.

Barth, M., Landsman, W., Lang, M., Williams, C., 2006. Accounting quality: international accounting standards and US GAAP. UNC Working paper.

Bekaert, G., Harvey, C.R., 1995. Time-varying world market integration. Journal of Finance 50 (2), 403-444.

Bekaert G. , Harvey, C.R., R. Lumsdaine, 2002. The dynamics of emerging market equity flows. Journal of International Money and Finance 21 (3), 295-350.

Black, F., 1974. International capital market equilibrium with investment barriers. Journal of Financial Economics 1 (4), 337-352.

Bohn, H., Tesar, L., 1996. U.S. equity investment in foreign markets: portfolio rebalancing or returns chasing? American Economic Review 86 (2), 77-81.

Brennan, M., Cao, H., 1997. International portfolio flows. Journal of Finance 52, 1851-1880. 
Brennan, M., Cao, H., Xu, X., 2005. The dynamics of international equity market expectations. Journal of Financial Economics 77 (2), 257-288.

Calvo, G., Leiderman, L., Reinhart, C., 1993. Capital inflows to Latin America: the role of external factors. IMF Staff Papers 40 (1), 108-151.

Campbell, J.Y., Lo, A.W., McKinlay, A.C., 1997. The Econometrics of Financial Markets. Princeton University Press, Princeton.

Campbell, J.Y., Shiller, R.,1988. Stock prices, earnings, and expected dividends. Journal of Finance 43 (3), 661-76.

Choe, H., Kho, C., Stulz, R., 2005. Do domestic investors have an edge? The trading experience of foreign investors in Korea. Review of Financial Studies 18 (3), 795-829.

Chuhan, P., Claessens, S., Mamingi, N., 1998. Equity and bond flows to Latin America and Asia:the role of global and country factors. Journal of Development Economics 55 (2), 439 463.

Claessens, S., Klingebiel, D., Schmukler, S., 2002. The future of stock exchanges in emerging economies: evolution and prospects. Brookings-Wharton Papers on Financial Services, 167202.

Croushore, D., Stark, T., 2001. A real-time data set for macroeconomists. Journal of Econometrics 105 (1), 111-130.

Doidge, C., Karolyi, A., Stulz, R., 2004. Why are foreign firms listed in the U.S. worth more? Journal of Financial Economics 71 (2), 208-235.

Dvorak, T., 2005. Do domestic investors have an information advantage? Evidence from Indonesia. Journal of Finance 60 (2), 817-839. 
Edison, H. J., Warnock, F., 2003. A simple measure of the intensity of capital controls. Journal of Empirical Finance 10 (1), 81-103.

Edison, H. J., Warnock, F., 2004. U.S. investors' emerging market equity portfolios: a securitylevel analysis. Review of Economics and Statistics 86 (3), 691-704.

Eichengreen, B., 2001. Capital account liberalizations: what do cross-country studies tell us? World Bank Economic Review 15 (3), 341-365.

Erb, C., Harvey, C., Viskanta, T., 1996. Political risk, economic risk, and financial risk. Financial Analysts Journal 52 (6), 28-46.

Fama, E., French, K., 1988. Dividend yields and expected stock returns. Journal of Financial Economics 22 (1), 3-16.

Foerster, S., Karolyi, G.A., 1999. The effects of market segmentation and investor recognition on asset prices: evidence from foreign stocks listing in the U.S. Journal of Finance 54 (3), 981-1013.

Frankel, J., Cavallo, E., 2004. Does openness to trade make countries more vulnerable to sudden stops, or less? Using gravity to establish causality. NBER Working Paper No. 10957.

Froot, K., O’Connell, P.G., Seasholes, M., 2001. The portfolio flows of international investors. Journal of Financial Economics 59 (2), 151-194.

Griever, W., Lee, G. , Warnock, F., 2001. The U.S. system for measuring cross-border investment in securities: a primer with a discussion of recent developments. Federal Reserve Bulletin 87 (10), 633-650.

Griffin, J., Nardari, F., Stulz, R., 2004. Are daily cross-border flows pushed or pulled? Review of Economics and Statistics 86 (3), 641-657. 
Grinblatt, M., Titman, S., Wermers, R., 1995. Momentum investment strategies, portfolio performance, and herding: a study of mutual fund behavior. American Economic Review 85 (5), 1088-1105.

Harvey, C., 1995. Predictable risk and returns in emerging markets. Review of Financial Studies $8(3), 773-816$.

Karolyi, G.A., 1998. Why do companies list shares abroad? A survey of the evidence and its managerial implications. Financial Markets, Institutions \& Instruments 7 (1), 1-60.

Karolyi, G.A., 2003. DaimlerChrysler AG, the first truly global share. Journal of Corporate Finance 9 (4), 409-430.

Karolyi, G.A., 2004. The role of ADRs in the development and integration of emerging equity markets. Review of Economics and Statistics 86 (3), 670-690.

Lang, M., Lins, K., Miller, D., 2003a. ADRs, analysts, and accuracy: does cross listing in the U.S. improve a firm's information environment and increase market value? Journal of Accounting Research 41 (2), 317-345.

Lang, M., Raedy, J., Yetman, M., 2003b. How representative are firms that are cross listed in the United States? An analysis of accounting quality. Journal of Accounting Research 41 (2), 363-386.

Leuz, C., Nanda, D., Wysocki, P., 2003. Earnings management and investor protection: an international comparison. Journal of Financial Economics 69 (3), 505-527.

Leuz, C., Triantis, A., Wang, T., 2006. Why do firms go dark? Causes and economic consequences of voluntary SEC deregistrations. mimeo, Chicago Business School.

Levine, R., 2001. International financial liberalization and economic growth. Review of International Economics 9 (4), 688-702. 
Lins, K., Strickland, D., Zenner, M., 2005. Do non-U.S. firms issue equity on U.S. stock exchanges to relax capital constraints? Journal of Financial and Quantitative Analysis 40 (1), 109-133.

Miller, D., 1999. The market reaction to international cross-listings: evidence from depositary receipts. Journal of Financial Economics 51 (1), 103-123.

Montiel, P., Reinhart, C., 1999. Do capital controls and macroeconomic policies influence the volume and composition of capital flows? Evidence from the 1990s. Journal of International Money and Finance 18 (4), 619-635.

Newey, W., West, K., 1987. A simple, positive semi-definite, heteroskedasticity and autocorrelation consistent covariance matrix. Econometrica 55 (3), 703-708.

Pagano, M., Roell, A., Zechner, J., 2002. The geography of equity listing: why do European companies list abroad? Journal of Finance 57 (6), 2651-2694.

Portes, R., Rey, H., 2005. The determinants of cross-border equity flows. Journal of International Economics 65 (2), 269-296.

Pulatkonak, M., Sofianos, G., 1999. The distribution of global trading in NYSE-listed non-U.S. stocks. NYSE Working Paper \#99-03.

Quinn, D., 1997. The correlates of changes in international financial regulation. American Political Science Review 91 (3), 531-551.

Richards, A., 2005. Big fish in small ponds: the momentum investing and price impact of foreign investors in Asian emerging equity markets. Journal of Financial and Quantitative Analysis $40(1), 1-27$. 
Rodrik, D., 1998. Who needs capital-account convertibility? In Fischer,S. et al. (eds.) Should the IMF Pursue Capital-Account Convertibility? Essays in International Finance, Princeton Unversity.

Seasholes, M., 2000. Smart foreign traders in emerging markets. mimeo, UC-Berkeley.

Stulz, R., 1981. On the effects of barriers to international investment. Journal of Finance 36 (4), 923-934.

Taylor, M., Sarno, L., 1997. Capital flows to developing countries: long- and short-term determinants. World Bank Economic Review 11 (3), 451-470.

Tesar, L., Werner, I., 1994. International equity transactions and U.S. portfolio choice. In Frankel, J., The Internationalization of Equity Markets. NBER and University of Chicago Press, Chicago.

Thomas, C., Warnock, F., Wongswan, J., 2006. The performance of international equity portfolios. NBER Working Paper 12346.

Tribukait, H., 2003. The invisible enforcer? price behavior of Mexican firms cross-listed on the NYSE around earnings announcements. mimeo, Harvard University.

Valkanov, R., 2003. Long-horizon regressions: theoretical results and applications. Journal of Financial Economics 68 (2), 201-232.

Warnock, F., Cleaver, C., 2003. Financial centers and the geography of capital flows. International Finance 6 (1), 27-59. 
Figure 1. Monthly Net Purchases of Equities by U.S. Investors (as a percentage of local market capitalization)

(a) Latin America

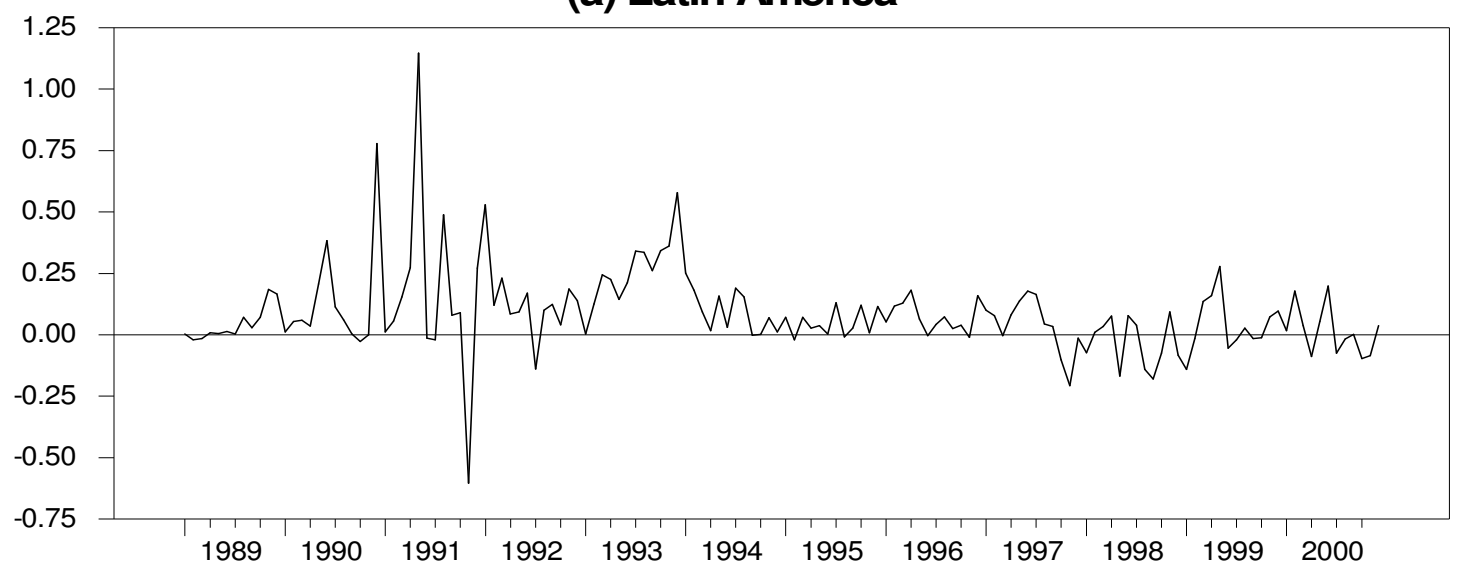

(b) Emerging Asia

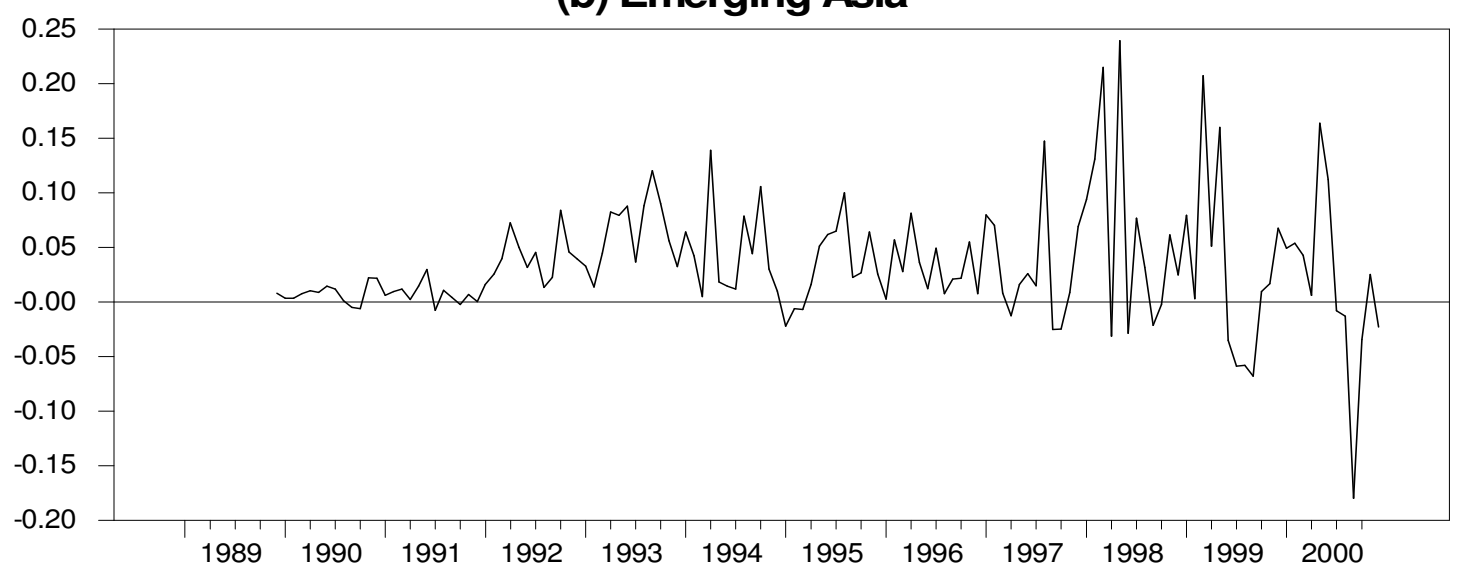




\section{Figure 2. Foreign Ownership Restrictions}

(a) Latin America

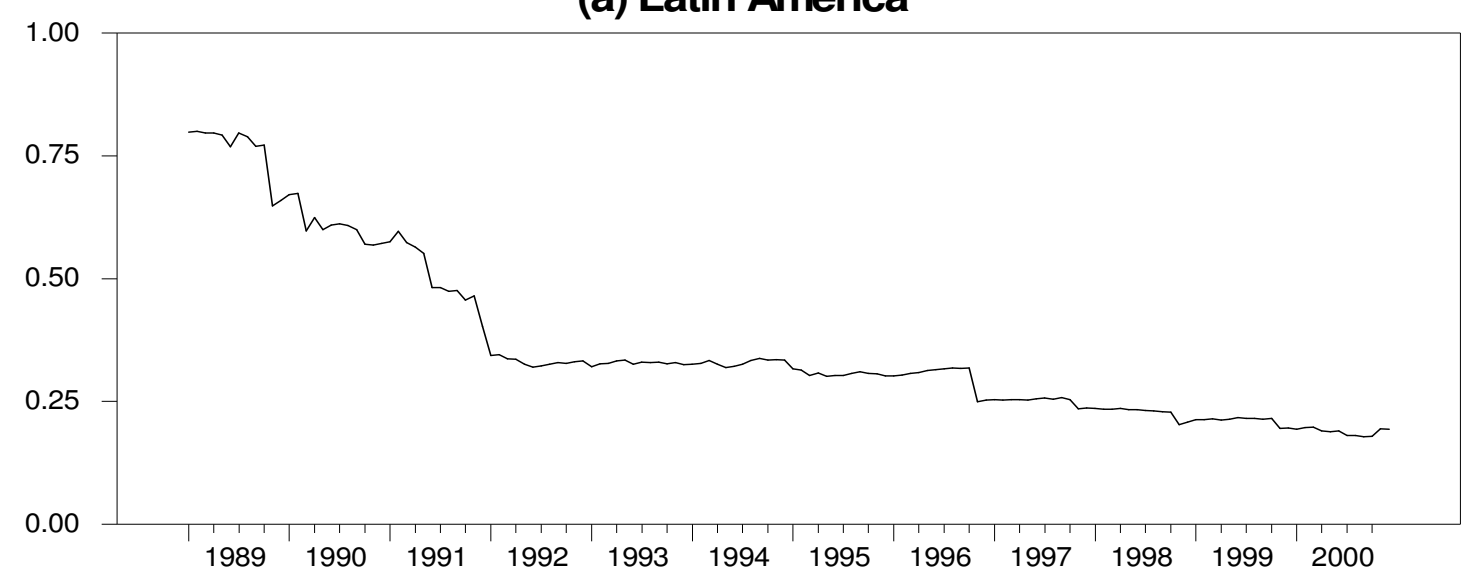

(b) Emerging Asia

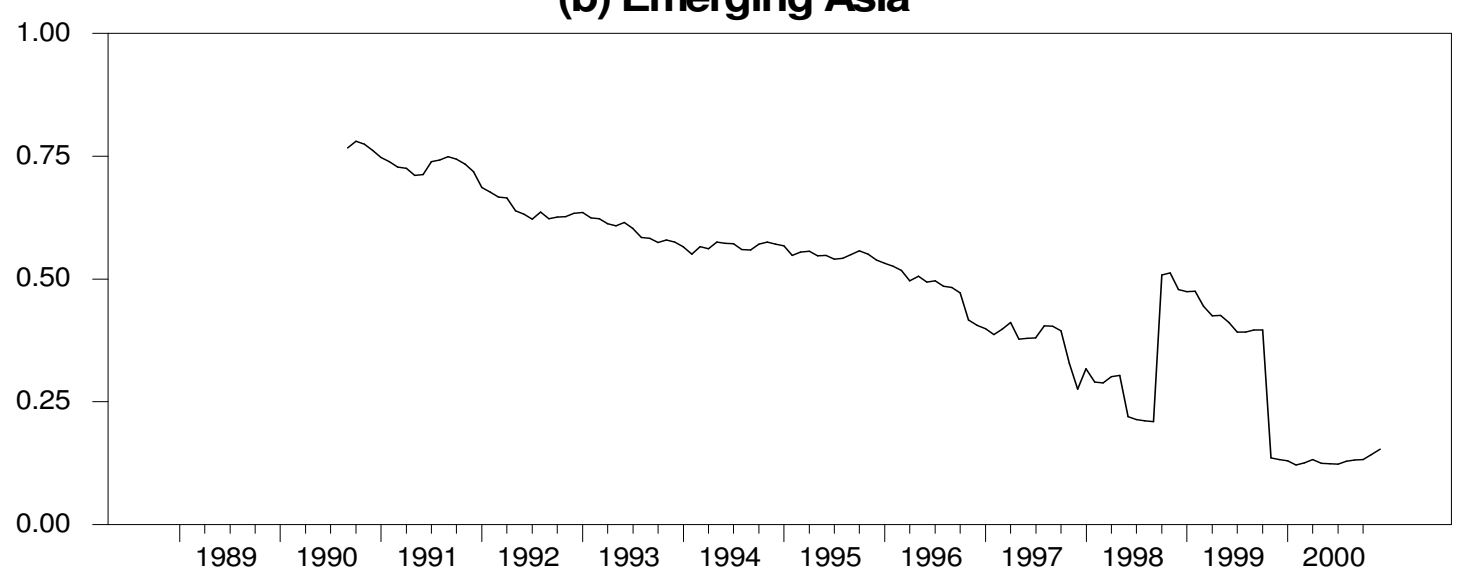


Figure 3. New Listings of Emerging Market Stocks on U.S. Exchanges (as a percent of local market capitalization)

(a) Latin America

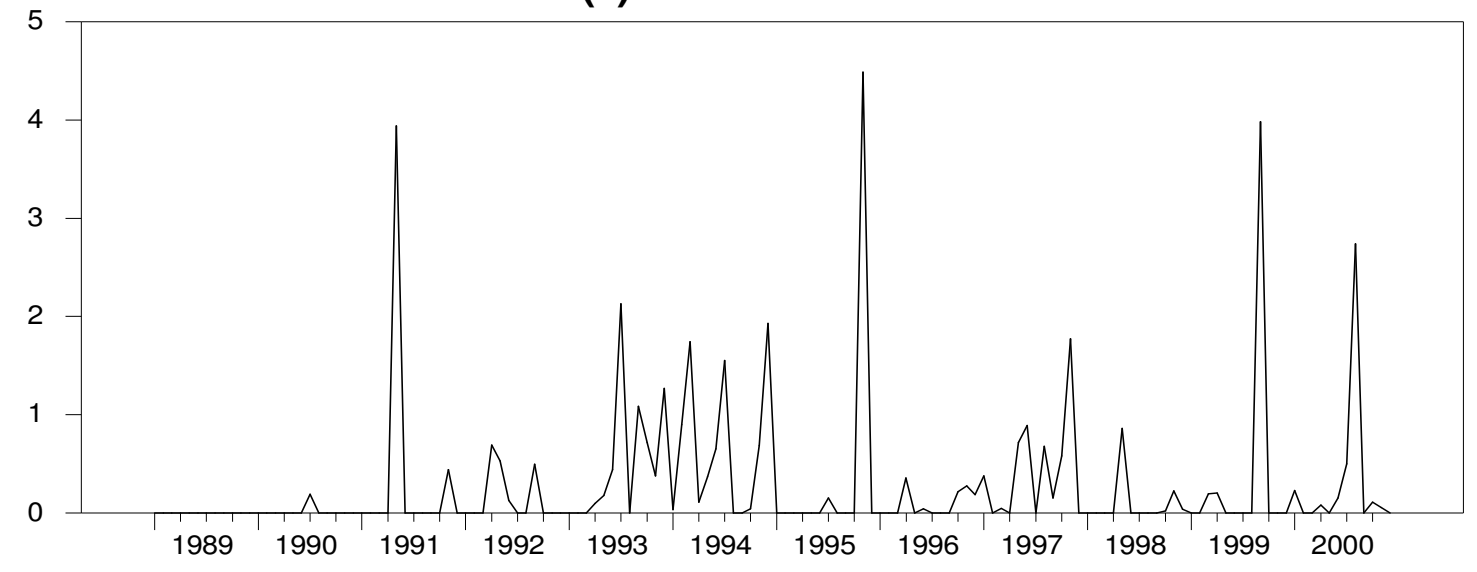

(b) Emerging Asia

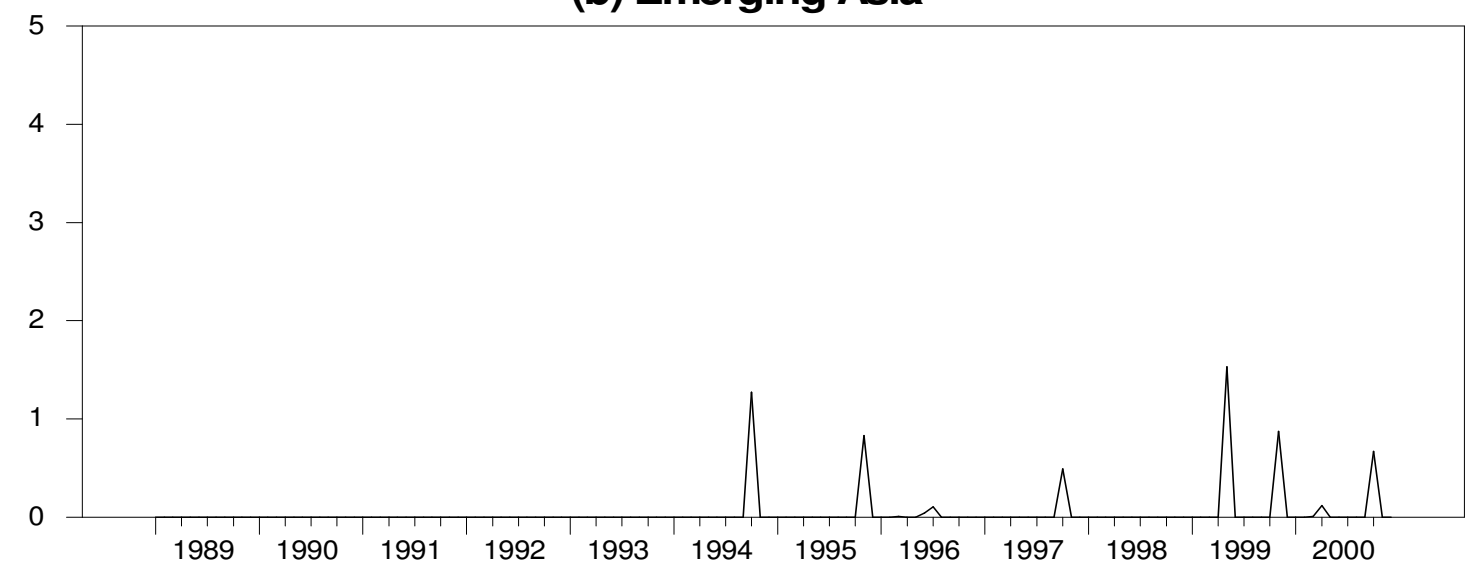




\section{Table 1: Capital Flow Data ${ }^{a}$}

\begin{tabular}{|c|c|c|c|c|c|c|c|c|c|c|c|}
\hline & 1989 & 1990 & 1991 & 1992 & 1993 & 1994 & 1995 & 1996 & 1997 & 1998 & 1999 \\
\hline \multicolumn{12}{|l|}{ Latin America and Caribbean } \\
\hline \multirow[t]{2}{*}{ 1. Total Flows (billions of US\$) } & 7.1 & 19.4 & 26.9 & 32.7 & 62.8 & 59.2 & 72.1 & 96.2 & 110.9 & 139.3 & 113.6 \\
\hline & \multicolumn{11}{|c|}{ (percent of total) } \\
\hline 2. Portfolio Equity Flows & 5.6 & 5.7 & 23.4 & 25.4 & 43.3 & 22.3 & 10.5 & 14.4 & 8.9 & 1.2 & 3.4 \\
\hline 3. Foreign Direct Investment & 114.1 & 42.3 & 48.0 & 45.9 & 21.8 & 48.0 & 41.3 & 45.0 & 58.7 & 51.8 & 79.6 \\
\hline 4. Net flow of long-term debt & -21.1 & 52.1 & 28.6 & 28.7 & 34.9 & 29.7 & 48.1 & 40.5 & 32.4 & 47.0 & 17.0 \\
\hline \multicolumn{12}{|l|}{ East Asia and Pacific } \\
\hline \multirow[t]{2}{*}{ 5.Total Flows (billions of US\$) } & 20.7 & 25.6 & 33.3 & 51.7 & 80.8 & 88.9 & 106.2 & 125.1 & 126.8 & 79.9 & 62.6 \\
\hline & \multicolumn{11}{|c|}{ (percent of total) } \\
\hline 6. Portfolio Equity Flows & 12.6 & 9.0 & 3.6 & 10.3 & 25.6 & 14.2 & 17.2 & 14.5 & 7.3 & 11.3 & 33.7 \\
\hline 7. Foreign Direct Investment & 44.0 & 43.4 & 42.6 & 42.6 & 49.0 & 52.2 & 50.0 & 48.8 & 51.7 & 79.2 & 89.5 \\
\hline 8. Net flow of long-term debt & 43.5 & 47.7 & 53.8 & 47.2 & 25.4 & 33.6 & 32.8 & 36.8 & 41.0 & 9.5 & -23.2 \\
\hline
\end{tabular}

a Data are from various issues of the World Bank's Global Development Finance publication. The regions in this table correspond with World Bank conventions and are much broader than those used in other tables and figures in this paper. 
Table 2: Net US purchases of emerging market stocks ${ }^{\mathrm{a}}$ (annual averages, in millions of US \$)

\begin{tabular}{lllll} 
& $\mathbf{1 9 7 7 - 8 7}$ & $\mathbf{1 9 8 8 - 9 2}$ & $\mathbf{1 9 9 3 - 9 7}$ & $\mathbf{1 9 9 8 - 9 9}$ \\
Argentina & 0 & 8 & 1,085 & $(395)$ \\
Brazil & 1 & 387 & 1,777 & 476 \\
Chile & $(1)$ & 45 & 388 & 147 \\
Mexico & 20 & 1,185 & 1,342 & 318 \\
Latin America & $\mathbf{2 0}$ & $\mathbf{1 , 6 2 4}$ & $\mathbf{4 , 5 9 2}$ & $\mathbf{5 4 6}$ \\
memo: world equity flows to & $\mathbf{1 9}$ & $\mathbf{2 , 9 5 0}$ & $\mathbf{1 2 , 0 6 0}$ & $\mathbf{2 , 4 6 1}$ \\
Latin America & & & & \\
Indonesia & $(0)$ & 58 & 528 & $(20)$ \\
Korea & 6 & 89 & 1,659 & 1,936 \\
Malaysia & 9 & 79 & 244 & $(263)$ \\
Philippines & 1 & 60 & 300 & 26 \\
Thailand & 4 & 77 & 36 & 16 \\
Asian emerging markets & $\mathbf{2 0}$ & $\mathbf{3 6 3}$ & $\mathbf{2 , 7 6 7}$ & $\mathbf{1 , 6 9 5}$ \\
memo: world equity flows to & $\mathbf{6 3}$ & $\mathbf{1 , 6 8 1}$ & $\mathbf{1 0 , 9 6 8}$ & $\mathbf{1 2 , 4 5 1}$ \\
Asian emerging markets & & & & 107,800 \\
U.S. Purchases of Foreign Equities & 1,288 & 17,818 & 63,460 & 109,500 \\
of which stock swaps & 0 & 0 & 4,000 & 0 \\
$\quad$ with emerging markets & 0 & 0 & 0 & . \\
\hline
\end{tabular}

${ }^{a}$ Surces: U.S. Department of Treasury, Treasury International Capital Reporting System; World Bank, Global Development Finance; Securities Data Corporation. 
Table 3. Summary Statistics ${ }^{\mathrm{a}}$

\begin{tabular}{|c|c|c|c|c|c|c|c|c|c|c|c|c|c|}
\hline \multicolumn{14}{|c|}{ Panel A. Latin America } \\
\hline & \multicolumn{5}{|c|}{ Descriptive Statistics } & \multicolumn{8}{|c|}{ Correlations } \\
\hline & mean & $\min$ & $\max$ & stderr & $\rho$ & $\mathrm{Y}_{\mathrm{t}}$ & RISK & DY & RET & CBL & USIP & USBOND & FOR \\
\hline$\sum \mathrm{Y}_{\mathrm{t}+\mathrm{k}} / 12$ & 0.084 & -0.156 & 0.752 & 0.135 & 0.976 & 0.473 & 0.048 & -0.140 & 0.009 & 0.146 & -0.454 & -0.171 & -0.003 \\
\hline$Y_{t}$ & 0.084 & -1.280 & 2.376 & 0.263 & 0.284 & & 0.041 & -0.080 & 0.092 & 0.439 & -0.230 & -0.108 & 0.023 \\
\hline RISK & 0.001 & -0.122 & 0.096 & 0.016 & 0.015 & & & -0.021 & 0.108 & -0.020 & -0.176 & 0.074 & -0.076 \\
\hline DY & 3.043 & 0.090 & 22.910 & 2.451 & 0.900 & & & & -0.163 & -0.006 & 0.209 & 0.307 & 0.009 \\
\hline RET & 1.103 & -69.004 & 95.841 & 14.011 & 0.025 & & & & & 0.010 & -0.122 & 0.069 & -0.007 \\
\hline CBL & 0.003 & 0.000 & 0.190 & 0.015 & -0.010 & & & & & & -0.067 & -0.058 & 0.018 \\
\hline USIP & 4.094 & -3.685 & 12.951 & 4.218 & 0.977 & & & & & & & 0.041 & 0.076 \\
\hline USBOND & 6.238 & 4.170 & 9.610 & 1.318 & 0.963 & & & & & & & & -0.020 \\
\hline FOR & -0.004 & -0.700 & 0.035 & 0.039 & -0.009 & & & & & & & & \\
\hline
\end{tabular}




\section{Panel B. Emerging Asia}

Descriptive Statistics

\begin{tabular}{|c|c|c|c|c|c|c|c|c|c|c|c|c|c|}
\hline & mean & $\min$ & $\max$ & stderr & $\rho$ & $\mathrm{Y}_{\mathrm{t}}$ & RISK & DY & RET & CBL & USIP & USBOND & FOR \\
\hline$\sum \mathrm{Y}_{\mathrm{t}+\mathrm{k}} / 12$ & 0.045 & -0.082 & 0.271 & 0.058 & 0.975 & 0.482 & -0.018 & -0.159 & -0.004 & 0.030 & -0.265 & -0.056 & -0.055 \\
\hline$Y_{t}$ & 0.046 & -0.301 & 0.976 & 0.113 & 0.217 & & 0.020 & -0.123 & 0.074 & 0.184 & -0.084 & -0.108 & -0.019 \\
\hline RISK & 0.001 & -0.157 & 0.144 & 0.020 & 0.204 & & & -0.242 & 0.133 & -0.027 & -0.133 & -0.031 & 0.069 \\
\hline DY & 1.610 & 0.070 & 7.670 & 0.992 & 0.913 & & & & -0.256 & -0.020 & 0.044 & 0.028 & 0.036 \\
\hline RET & -0.845 & -36.537 & 69.421 & 11.987 & 0.126 & & & & & 0.069 & -0.071 & -0.226 & 0.060 \\
\hline CBL & 0.001 & 0.000 & 0.189 & 0.012 & -0.010 & & & & & & 0.044 & 0.028 & -0.005 \\
\hline USIP & 3.975 & -3.685 & 12.951 & 4.541 & 0.962 & & & & & & & -0.035 & -0.047 \\
\hline USBOND & 5.790 & 4.170 & 7.740 & 0.906 & 0.944 & & & & & & & & -0.044 \\
\hline FOR & -0.004 & -0.940 & 0.912 & 0.061 & -0.004 & & & & & & & & \\
\hline
\end{tabular}

${ }^{a}$ Data are for the Latin American and Emerging Asian panels. Y is monthly net U.S. purchases of the country $i$ 's equities normalized by country $i$ 's market capitalization. RISK is the log first difference of the ICRG Composite Risk. DY is the dividend yield. RET is the difference in rates of return on equities in country $i$ and the US. CBL is the relative size (firm market capitalization as a share of home country market capitalization) of a cross-listing on a US exchange. USIP is the deviation of real-time US industrial production from a time trend. USBOND is the rate on a medium-term US bond. FOR is the first difference of the intensity of foreign ownership restrictions. Further details on the variables are provided in the appendix. 
Table 4: Panel data estimates of short-horizon equity flows ${ }^{\mathrm{a}}$

\begin{tabular}{lcc} 
& Latin America & Asia \\
& & \\
RISK & 0.229 & 0.060 \\
& $(0.708)$ & $(0.781)$ \\
DY & 0.005 & $1.7 \mathrm{E}-4$ \\
& $(0.138)$ & $(0.972)$ \\
RET & $0.001^{*}$ & $2.9 \mathrm{E}-4$ \\
& $(0.052)$ & $(0.544)$ \\
FOR & $0.185^{* * *}$ & -0.037 \\
& $(0.002)$ & $(0.207)$ \\
CBL & $7.46^{* * *}$ & $1.47^{* * *}$ \\
& $(0.001)$ & $(0.004)$ \\
USIP & $-0.012^{* * *}$ & $-0.002^{* *}$ \\
& $(0.000)$ & $(0.040)$ \\
USBOND & $-0.019^{* *}$ & $-0.014^{* * *}$ \\
\multirow{2}{*}{$\mathrm{R}^{2}$} & $(0.012)$ & $(0.003)$ \\
\hline
\end{tabular}

a Dependent variable is monthly net U.S. purchases of the country $i$ 's equities normalized by country $i$ 's market capitalization. Samples, which start in January 1989 (Latin America) and November 1990 (Emerging Asia), are through 1999. All independent variables are at time $t-1$, except CBL and FOR, which are dated at time $t$. See Table 3 for a description of the independent variables. Constants are included but not reported. P-values computed using Newey and West (1987) standard errors are in parentheses. $^{* * *},{ }^{* * *}$, and ${ }^{*}$ indicate significance at the 1,5 , and 10 percent levels. 
Table 5: Panel data estimates of long-horizon equity flows ${ }^{\mathrm{a}}$

\begin{tabular}{lcc}
\hline & Latin America & Asia \\
RISK & -0.167 & \\
& $(0.508)$ & -0.083 \\
DY & 0.005 & $(0.539)$ \\
& $(0.312)$ & 0.004 \\
RET & $-2.6 \mathrm{E}-4$ & $(0.266)$ \\
& $(0.415)$ & $-9.0 \mathrm{E}-5$ \\
FOR & 0.064 & $(0.598)$ \\
& $(0.503)$ & $-0.046^{*}$ \\
CBL & $0.960^{* *}$ & $(0.052)$ \\
& $(0.025)$ & -0.089 \\
USIP & $-0.015^{* * *}$ & $(0.416)$ \\
& $(0.000)$ & $-0.004^{* * *}$ \\
USBOND & -0.017 & $(0.004)$ \\
& $(0.212)$ & -0.005 \\
& 0.27 & $(0.347)$ \\
& & 0.46 \\
\hline
\end{tabular}

a Dependent variable is average 12-month net US purchases of country $i$ 's equities normalized by country $i$ 's market capitalization. Samples, which start in January 1989 (Latin America) and November 1990 (Emerging Asia), are through 1999. All independent variables are at time $t-1$, except CBL and FOR, which are dated at time $t$. See Table 3 for a description of the independent variables. Constants are included but not reported. P-values computed using Newey and West (1987) standard errors are in parentheses. ${ }^{* * *},{ }^{* *}$, and ${ }^{*}$ indicate significance at the 1,5 , and 10 percent levels. 